\title{
Review \\ Developments in the clinical understanding of rheumatoid arthritis
} Josef S Smolen and Daniel Aletaha

\begin{abstract}
Division of Rheumatology, Department of Internal Medicine III, Medical University of Vienna, and 2nd Department of Medicine, Hietzing Hospital, Waehringer Guertel 18-20, A-1090 Vienna, Austria
\end{abstract}

Corresponding author: Josef S Smolen, josef.smolen@wienkav.at

Published: 30 January 2009

This article is online at http://arthritis-research.com/content/11/1/204

(c) 2009 BioMed Central Ltd

Arthritis Research \& Therapy 2009, 11:204 (doi:10.1186/ar2535)

virtually iconoclastic. Therefore, in this review, we will devote a separate section to each of these four developments.

\section{A. Influencing major characteristics of the disease}

\section{A new look at assessing active disease}

\section{Clinical fact 1}

Composite indices are the best depicters of disease activity. The degree of disease activity at the start of a disease-modifying therapy is a major determinant of the disease activity attainable in treatment. supports the optimization of the therapeutic approaches. Finally, with the advent of novel therapies, remission has become a reality and the treatment algorithms encompassing all of the abovementioned aspects will allow us to achieve the rigorous aspirations of today and tomorrow.

Rheumatologists and people with arthritis whose memories span the last two decades have witnessed developments in the clinical understanding of rheumatoid arthritis (RA) which most would have regarded as science fiction had someone predicted them. These ( $r$ )evolutionary changes relate (a) to the possibility of influencing all major characteristics associated with the disease: signs and symptoms, joint damage, disability, quality of life, and other important outcomes like joint replacement and working capacity, comorbidity, and economic consequences, (b) to the reporting of clinical trial results, (c) to the recognition of time as an important element not only in the progression of RA but also in our treatment strategies when it comes both to early therapeutic interference and to swift switching of therapies, and (d) to the profoundness of the response to novel therapies and therapeutic strategies. Because these advances have entailed profound changes in paradigms, they can be seen as

\section{Background and evidence}

The pivotal clinical manifestation of RA is a polyarticular synovitis, which is a consequence of the underlying cellular and molecular inflammatory events leading to pain, swelling due to synovial thickening and effusion, and stiffness of the joints. While initially individual signs and symptoms, such as swollen joint counts or morning stiffness, or laboratory variables, such as erythrocyte sedimentation rate or C-reactive protein (CRP), have been thought to sufficiently reflect activity and were used to follow patients in clinical practice, it was the parallel activities of clinical researchers in Europe and the US and of committees of the American College of Rheumatology, the European League Against Rheumatism, and the International League against Rheumatism which led to the recognition that only a limited number of variables were reliable and sensitive to change and that composite indices using such a limited spectrum of disease characteristics would capture disease activity best in terms of reliability, validity, applicability across patients, and sensitivity to change [1-9]. Indeed, the individual components of these 'core sets' reflect different aspects of RA. For example, swollen joint

$\mathrm{ACR} 70 \%=\mathrm{a} 70 \%$ improvement in symptoms according to the American College of Rheumatology criteria; CDAI = Clinical Disease Activity Index; $\mathrm{CRP}=\mathrm{C}$-reactive protein; DAS28 = disease activity score using 28 joint counts; DMARD = disease-modifying anti-rheumatic drug; $\mathrm{HAQ}=$ health assessment questionnaire; IL = interleukin; MTX = methotrexate; RA = rheumatoid arthritis; SDAI = Simplified Disease Activity Index; SF-36 = short form-36; TNF $=$ tumor necrosis factor. 
counts and acute-phase reactants are best associated with joint damage [10-12], even though the correlation between swollen joint counts and acute-phase response is relatively weak. In contrast, functional impairment is best associated with tender joint counts $[10,12]$. These few examples show that composite indices encapsulate variables that relate to the spectrum of RA and that they also comprise information provided by the evaluator, the patient, or both and often an 'objective' laboratory variable as well [13]. Consequently, changes in these scores, response criteria using these instruments, or disease activity states employing these indices to categorize the extent of disease expression have provided important information about the relation of the range of disease activity with intermediate and long-term outcomes and have been pivotal in our evaluation of therapeutic success in clinical trials $[5,7,8,13]$. Importantly, however, it appears that the degree of disease activity at any point in time, such as at the beginning of a new treatment course, is an important predictor, on the group level, of disease activity in the longer term, even with effective therapy [14].

\section{Disease activity is the driver of joint damage}

\author{
Clinical fact 2 \\ Joint damage is a consequence of the \\ inflammatory process (disease activity over \\ time). Joint space narrowing and erosions by \\ radiography depict related but distinct \\ components of joint damage that may develop \\ separately.
}

\section{Background and evidence}

The hallmark of RA that distinguishes it most from all other arthritides is the damage elicited in the joints. The RA synovial membrane directly invades bone, entailing osteoclast activation to carry out this job $[15,16]$. Likewise, the products activated in the course of the inflammatory response, whether originating from synovial cells or chondrocytes, lead to degradation of the cartilage matrix $[17,18]$. All of these events are a consequence of the activation of many cell populations and, ultimately, of the upregulation of proinflammatory cytokines $[19,20]$. By whichever means they themselves become activated, they induce a plethora of inflammatory products, including degradative enzymes, which mediate most if not all of the total phenotypic expression of RA, including joint destruction. The fact that CRP is induced by the proinflammatory cytokine interleukin-6 (IL-6) and the observation that CRP levels over time correlate with joint damage $[10,21]$ indirectly link joint damage to the inflammatory cytokine levels. However, as indicated before, the correlation of CRP with joint destruction is lower than that of swollen joint counts but higher than that of tender joint counts.

It has been unequivocally shown that the relationship of time averaged disease activity, and its change in response to therapy, as assessed by various composite indices, correlates well with the extent of radiographic joint damage or the degree of inhibition of its progression, respectively $[1,8,21,22]$. These correlations pertain to both cartilage damage, as reflected radiologically by joint space narrowing, and bone destruction, as depicted by erosions, which can be captured reliably and validly using respective scores [23]. Recent data suggest that these two processes may be related but distinct and can be separated by detailed analyses and even by specific therapies $[24,25]$.

\section{Disability is a multifarious feature}

\section{Clinical fact 3}

Disability comprises an activity-related component that is fully reversible and a destruction-related component that is irreversible. Clinical trial design needs to account for this complexity. Interference with disease activity will reverse the activity-related segment and prevent the accrual of the damage-related part.

Background and evidence

Failure of functioning is the most critical endpoint for an organ or an individual. In RA, physical functioning is the major outcome of interest given the impact of its impairment on the person, the family, and society. Various instruments have been developed to capture disability and its consequences on quality of life, and the most frequently used ones in RA are the health assessment questionnaire (HAQ) disability index and the short form-36 (SF-36), including its physical component subscale $[26,27]$. However, disability is a complex feature: it comprises disease-specific as well as non-diseasespecific elements. Among the latter, psychological well-being (which may or may not be related to RA), comorbidities (which may or may not be related to RA or its treatment), and age constitute important determinants [28]. However, the disease-specific portion has at least two components since pain and stiffness impair physical function even in the absence of joint damage (such as in very early active disease), while patients with severely destroyed joints may suffer from disability even in the absence of any disease activity. Indeed, several studies have directly or indirectly provided evidence of this bicomponential nature of the $\mathrm{HAQ}$ index [29-31]. Importantly, however, with increasing joint destruction, there is an increase in irreversible disability, even in states of stringent clinical remission [31]. Thus, in these patients, the floor that can be reached rests at a higher level. Therefore, irreversible disability can be averted only by prevention of joint destruction, which (as discussed above) is a consequence of disease activity. Since joint damage is also related to the duration of the disease, similar associations of reversibility and irreversibility can be found for disease duration [31] and similar findings can be made using a more 
generic quality-of-life instrument such as the SF-36. Importantly, however, these observations have a bearing on the response to therapy: in clinical trials of patients with longstanding disease, the functional improvement may be limited to an extent that does not allow one to discern active effective medication from placebo [32]; this indicates the importance of careful clinical trial design that accounts for the potential irreversible disability. Importantly, instruments enabling clinicians and trialists to predict the degree of reversibility of functional impairment would be desirable.

\section{Inter-relationship of disease activity and disability with various secondary outcomes characteristic of rheumatoid arthritis, such as comorbidity, mortality, and costs}

\author{
Clinical fact 4 \\ The reduction in life expectancy as well as \\ comorbidities associated with rheumatoid \\ arthritis (RA), such as cardiovascular disease \\ and lymphoma, and economic consequences, \\ including loss of working capacity, are \\ associated primarily with the severity of RA as \\ manifested by chronic high disease activity \\ and long-term irreversible disability.
}

\section{Background and evidence}

Mortality is increased in patients with RA. This reduction in life expectancy has been shown unequivocally to be related to the chronic active disease process and the associated disability [33-37]. However, mortality is due primarily to comorbidities, and among those conditions cardiovascular events are particularly relevant $[38,39]$. Importantly, cardiovascular disease is highly related to the inflammatory response [40,41]. Likewise, the prevalence of lymphoma is increased in RA and has been shown to be associated with the degree of inflammation and thus, again, chronic active disabling disease $[38,42]$.

RA also leads to multiple economic consequences. While addressing health economics in a broader sense is beyond the scope of this article, it needs to be mentioned that direct medical costs comprise not only costs for drugs but also those for other medical attention (including joint surgery) and that, with increasing $\mathrm{HAQ}$ scores, joint replacement surgery and use of other health care resources increase dramatically [43-45]. Among the many indirect costs, work disability constitutes an important economic consequence of RA. Within 10 years, up to $60 \%$ of RA patients may be fully or partly work-incapacitated [46-48]. Again, this is directly related to HAQ scores $[46,48,49]$. Thus, active disabling disease is generally associated with higher direct and indirect costs in RA [45,50,51]. Therefore, disease activity, as a sequel to the inflammatory events, directly or indirectly steers all of the characteristics and consequences of RA (Figure 1),

\section{Figure 1}

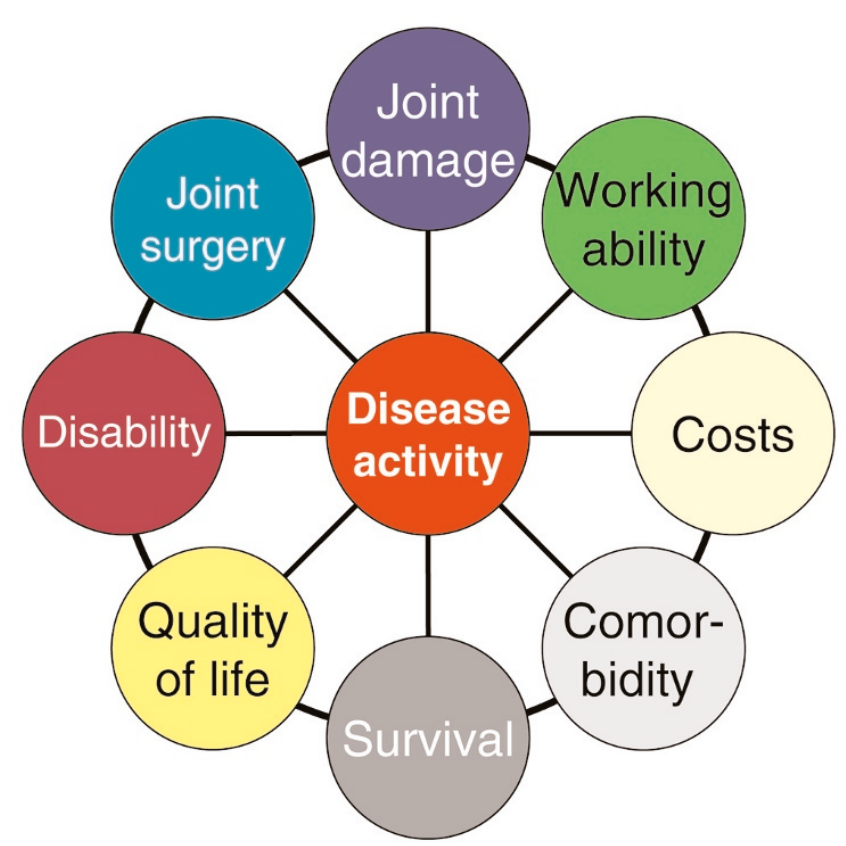

Inter-relationship of disease activity and outcomes in rheumatoid arthritis: a spinning wheel.

which in turn have partial influence on each other as further detailed in this commentary.

\section{B. The importance of appropriate disease activity reporting}

\section{It's the state, not just the change}

\section{Clinical fact 5}

Therapy for rheumatoid arthritis needs to aim at least to achieve low disease activity by composite scores and, ideally, remission.

Clinical trial reporting has to account for both improvement and disease activity categories, and the latter also needs to be evaluated during follow-up in clinical practice.

\section{Background and evidence}

Disease activity is rarely a dichotomous quality (active versus inactive) but, like temperature, constitutes a continuum. Composite disease activity indices, but also visual analogue scales or joint counts, are like a thermometer, reflecting this by providing a continuous measure. Nevertheless, to understand the impact of disease activity on the vast arrays of outcomes in RA, to select patients for clinical trials, to interpret laboratory findings or results from basic scientific 
investigations, to judge the indication or the necessity to change therapy, and to define the most appropriate therapeutic aims, categorical criteria are helpful. Therefore, categories or states of high, moderate, and low disease activity as well as remission have been identified for the most commonly used indices: the disease activity score (DAS), disease activity score using 28 joint counts (DAS28), Simplified Disease Activity Index (SDAI), and Clinical Disease Activity Index (CDAl) [13]. Indeed, the lower the disease activity category that can be attained under therapy, the lower the progression of joint damage [12,22].

On the other hand, in clinical practice and clinical trials, response to or improvement of therapy has been the center of attention [5,52]. Improvement or response, however, relates primarily to absolute or relative changes of disease activity, and actual activity at the endpoint will depend on the baseline values. Thus, response criteria do not account, or at least do not sufficiently account, for the disease activity state to be aimed for. This is further supported by observations that a symptom state acceptable to patients requires greater amounts of improvement as baseline disease activity increases. This reveals that the achievement of a particular state is the major desirable goal for patients [53]. Indeed, patients with an approximately $50 \%$ or higher improvement of their disease activity will suffer from continuing profound joint destruction if their disease activity is not brought into at least the low disease activity category [54]. Furthermore, even in states of low disease activity, there is a smoldering progression of joint damage with therapies like methotrexate (MTX), and therefore only remission leads to the arrest of joint damage [22].

On the basis of the above, achieving remission ought to be the ultimate goal when treating RA. The definition of remission, however, is still under debate and many rheumatologists would like to see remission defined as a state of no residual disease activity [12]. Nevertheless, some of the composite scores allow for significant residual disease activity and currently the most stringent remission criteria appear to be those defined by the SDAI and CDAl. Indeed, only when remission by these criteria is fulfilled will patients stop destroying their joints and reduce their functional impairment maximally and thus possibly to normality [54], regardless of their level of improvement.

These and other insights mandate a change in clinical trial reporting by requesting the provision of information on categories of disease activity attained in the course of a trial and at the endpoint rather than just providing levels of improvement [55]. Indeed, the first randomized double-blind controlled trial using a state as the primary endpoint has recently been published [56]. Thus, assessing disease activity has undergone major changes and has become both standardized and the standard of care. Such assessment is also important in clinical practice.

\section{Time and timing as well as appropriate follow-up are important facets of rheumatoid arthritis and the care for rheumatoid arthritis}

\section{Early recognition and therapy are mandates}

\author{
Clinical fact 6 \\ Early recognition of rheumatoid arthritis is \\ important for early institution of disease- \\ modifying anti-rheumatic drug therapy, which \\ is more efficacious than delayed treatment.
}

\section{Background and evidence}

The destructive process of RA starts within the first few weeks or months of disease, and by 2 years the majority of patients have damaged joints [57,58]. Indeed, there is evidence from experimental arthritis that osteoclast activation may occur even before the onset of clinical symptoms [59]. Several trials have revealed that early institution of diseasemodifying anti-rheumatic drug (DMARD) therapy, when compared with late start, improves the outcome of RA [6062]. The major gain is twofold: it appears that the more established disease may be somewhat less responsive to the same drugs when compared with early disease [62] ('window of opportunity'). The second asset is the earlier prevention of accrual of damage and thus an overall reduction in joint destruction and risk of irreversible disability. However, early therapy requires early diagnosis. Alas, current criteria for the classification of RA are based on patients with long-standing RA and criteria for early RA are needed and awaited [63].

\section{Regular tight follow-up and change of therapy are important}

\section{Clinical fact 7}

Tight follow-up examinations (every 3 months) and appropriate switch of therapy after a maximum of 3 to 6 months in patients who do not achieve low disease activity or remission are important constituents of modern therapeutic approaches to rheumatoid arthritis.

\section{Background and evidence}

Another aspect of time relates to the observation that chronic active disease, despite therapy, will lead to increasing joint damage (see above). Therefore, treatment that does not reduce disease activity to a low state should be switched rapidly. Since in clinical trials maximal therapeutic responsiveness can be seen within 3 to 6 months and since disease activity at 3 to 6 months is an excellent predictor of activity at 12 months [14], all necessary decisions can be made at that time, for the sake of the patient and consequently for society. However, this requires tightly timed control examinations and definitions of thresholds for switching insufficiently effective 
therapies. Indeed, following such an algorithm has allowed for better outcomes [64-66].

\section{New therapies and therapeutic strategies have revolutionized clinical developments}

\section{Tumor necrosis factor inhibitors plus methotrexate lead to profound clinical responses and uncouple the close relationship between disease activity and joint damage}

\author{
Clinical fact 8 \\ Remission has become a highly achievable \\ goal with the advent of biological therapies. \\ Moreover, tumor necrosis factor inhibitors plus \\ methotrexate significantly retard joint damage, \\ even in patients who do not respond well \\ clinically, thus reducing the propensity to \\ accumulate irreversible disability with active \\ disease.
}

\section{Background and evidence}

As indicated before, achieving low disease activity and remission need to be the ultimate therapeutic goals in RA in order to affect all of its attributes, which comprise destruction of bone and cartilage and accumulation of irreversible disability. The introduction of tumor necrosis factor (TNF) inhibitors, particularly in combination with MTX, has revolutionized the scene in this regard: never before have response rates been so profound, with ACR70\% (a 70\% improvement in symptoms according to the American College of Rheumatology criteria) improvement criteria fulfilled in up to about $40 \%$ of patients [67]. While proportions of patients with 'DAS28 remission' often exceed ACR70\% response rates, stringent remission according to the SDAl criteria has been observed at the end of a 1-year trial of a TNF inhibitor plus MTX in more than $20 \%$ of patients, whereas less than 15\% of patients remained in the high disease activity category; in contrast, almost $30 \%$ of patients treated with MTX monotherapy still resided at high disease activity levels and approximately $12 \%$ had attained remission at 1 year [22]. In clinical practice, this success can be surpassed: in our clinic, about $25 \%$ of patients are in SDAI remission and only about $5 \%$ are in high disease activity [68]; this is in line with findings that most patients in today's clinical practice do not fulfill entry criteria for clinical trials [69]. A scenario in which 1 in 4 patients has reached remission and only 1 in 20 resides in high disease activity is a dream that probably no rheumatologist would have dared to entertain just few years ago - a novel reality challenging us to aim for more.

One of the most surprising findings in the decade since the introduction of TNF inhibitors was the observation that TNF inhibitors in combination with MTX would arrest or at least significantly retard progression of joint damage even in patients with highly active RA despite anti-TNF plus MTX treatment and even in those who had no clinical benefit at all
[70]. This indicated that TNF blockade plus MTX uncoupled the tight linkage between clinical disease activity and joint damage, and these findings were confirmed in other studies [71]. Although the underlying mechanisms responsible for these findings have not been worked out, they may have to do with threshold levels of bioactive TNF [72]. Importantly, in contrast to MTX monotherapy, the combination with MTX arrested progression of joint damage in patients who achieved low disease activity rather than remission and retarded it significantly even in those who had moderate or high disease activity [22]. Nevertheless, also with TNF inhibitor plus MTX therapy, progression of joint destruction increased with increasing disease activity, albeit at a lower level and slope [22].

\section{Extinction of extra-articular manifestations and amyloidosis}

\author{
Clinical fact 9 \\ Effective therapy, in particular with \\ methotrexate (MTX) and more pronounced \\ with biologicals plus MTX, has abolished the \\ bulk of extra-articular manifestations and \\ amyloidosis, has reduced disease-related \\ comorbidity such as cardiovascular disease \\ and lymphoma, and has essentially normalized \\ life expectancy.
}

\section{Background and evidence}

Extra-articular manifestations and complications have been major causes of death in RA. These abnormalities concerned mainly the occurrence of vasculitis, secondary amyloidosis, malignancy, infections, and cardiac events. All of them have been related to the severity of the disease [73-75]. Already with its appropriate use (that is, by rapid escalation and employing high enough doses $[76,77])$, MTX was found to interfere with disease activity and thus to reduce the levels of rheumatoid factor and acute-phase reactants. In particular, vasculitis and amyloidosis became rare due to the better control of disease activity. Moreover, the incidences of lymphoma and cardiovascular disease have declined significantly, leading to increased survival rates [42,78]. The improvement in all of these outcomes appears to have been uniformly expanded by the advent of TNF inhibitors, which allowed clinicians to further reduce the clinical and serological disease activity $[79,80]$, resulting in further improved survival - at least in observational studies $[81,82]$.

\section{The novel therapies allow for a modification of treatment strategies and have significant economic consequences}

\section{Clinical fact 10}

Novel algorithms that encompass regular disease activity assessment, change or modification of therapy upon insufficient 
response defined as a lack of achievement of low disease activity or even remission, and the use of glucocorticoids and biological agents may allow for rapid achievement of optimal therapeutic responses in the vast majority of patients. This will not only improve quality of life but also lead to a reduction in the need for joint surgery and to the preservation of working ability.

\section{Background and evidence}

With the availability of biological agents that today comprise not only TNF and IL-1 inhibitors but also a B-cell-depleting agent, a co-stimulation inhibitor, and (currently in Japan and likely in the near future in other parts of the world) an IL-6 receptor antibody, the armamentarium to treat $R A$ has dramatically expanded [67]. The concomitant insights that patients in clinical practice also should be followed using composite indices and ought to be tightly controlled, the significant effect of switching therapy if predefined low disease activity criteria are not reached [64,66], and the finding that long-term efficacy can be predicted within the short term after starting treatment [14] have allowed for the introduction of treatment algorithms that might further improve outcome in RA [83]. Additional information from clinical trials has also revealed that the combination of synthetic DMARDs with glucocorticoids has significant efficacy that may come close to that of the combination of DMARDs with biological agents [66,84-87]. In contrast, the usefulness of combining synthetic DMARDs without the addition of glucocorticoids is still unresolved $[66,88]$.

The profound efficacy of novel treatment strategies, including biological agents, on disease activity, joint destruction, physical function, and quality of life also has profound consequences on economic aspects. On the one hand, these agents are costly and may not be affordable under many circumstances. On the other hand, effective therapy ought to lead to a reduction in other direct and indirect costs that are afforded otherwise. This cost reduction is, indeed, seen. For example, in parallel to the advent of novel therapies, the necessity to perform joint replacement surgery has decreased: while in the last decade approximately 530 total hip joint replacements per year were performed in Sweden in patients with inflammatory arthritis, this number steadily declined in the present decade to approximately 300 in 2006, contrasting their increase in osteoarthritis [89]. Likewise, employment rates and employability increase in the course of effective therapy [49], suggesting the resurrection or maintenance of the working capacity of patients, reduction of early retirement rates, and improvement or preservation of quality of life.

Taken as a whole, our clinical understanding of RA has expanded significantly over the past decade. These developments have already dramatically changed or will be realized in the near future in clinical trial design and clinical

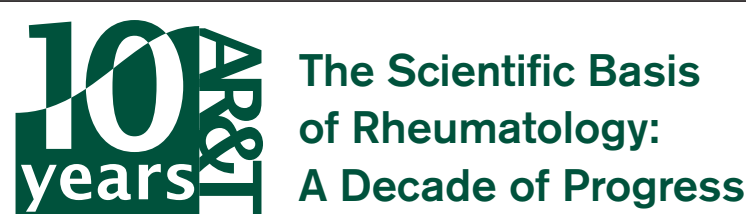

This article is part of a special collection of reviews, The Scientific Basis of Rheumatology: A Decade of Progress, published to mark Arthritis Research \& Therapy's 10th anniversary.

Other articles in this series can be found at: http://arthritis-research.com/sbr

practice, allowing further improvements in the approach to successful therapy of RA.

\section{Competing interests}

The authors declare that they have no competing interests.

\section{References}

1. van der Heijde DM, van't Hof MA, van Riel PL, van Leeuwen MA, van Rijswijk $\mathrm{MH}$, van de Putte LB: Validity of single variables and composite indices for measuring disease activity in rheumatoid arthritis. Ann Rheum Dis 1992, 51:177-181.

2. Prevoo MLL, van't Hof MA, Kuper HH, van de Putte LBA, van Riel PLCM: Modified disease activity scores that include twentyeight-joint counts. Development and validation in a prospective longitudinal study of patients with rheumatoid arthritis. Arthritis Rheum 1995, 38:44-48.

3. Scott DL, Panayi GS, van Riel PL, Smolen J, van de Putte LB: Disease activity in rheumatoid arthritis: preliminary report of the Consensus Study Group of the European Workshop for Rheumatology Research. Clin Exp Rheumatol 1992, 10:521-525.

4. Felson DT, Anderson JJ, Boers M, Bombardier C, Chernoff M, Fried B, Furst D, Goldsmith C, Kieszak S, Lightfoot R, Paulus H, Tugwell P, Weinblatt M, Widmark R, Williams HJ, Wolfe F: The American College of Rheumatology preliminary core set of disease activity measures for rheumatoid arthritis. The Committee on Outcome Measures in Rheumatoid Arthritis Clinical Trials. Arthritis Rheum 1993, 36:729-740.

5. Felson DT, Anderson JJ, Boers M, Bombardier C, Furst D, Goldsmith C, Katz LM, Lightfoot R Jr, Paulus H, Strand V, Tugwell P, Weinblatt M, Williams HJ, Wolfe F, Kieszak S: American College of Rheumatology preliminary definition of improvement in rheumatoid arthritis. Arthritis Rheum 1995, 38:727-735.

6. Boers M, Tugwell P, Felson DT, van Riel PL, Kirwan JR, Edmonds JP, Smolen JS, Khaltaev N, Muirden KD: World Health Organization and International League of Associations for Rheumatology core endpoints for symptom modifying antirheumatic drugs in rheumatoid arthritis clinical trials. J Rheumatol Suppl 1994, 41:86-89.

7. van Gestel AM, Prevoo MLL, van't Hof MA, van Rijswijk MH, van de Putte LBA, van Riel PLCM: Development and validation of the European League Against Rheumatism response criteria for rheumatoid arthritis: comparison with the preliminary American College of Rheumatology and the World Health Organization/International League Against Rheumatism Criteria. Arthritis Rheum 1996, 39:34-40.

8. Smolen JS, Breedveld FC, Schiff MH, Kalden JR, Emery P, Eberl $G$, van Riel PL, Tugwell P: A simplified disease activity index for rheumatoid arthritis for use in clinical practice. Rheumatology (Oxford) 2003, 42:244-257.

9. Goldsmith $\mathrm{CH}$, Boers M, Bombardier C, Tugwell P: Criteria for clinically important changes in outcomes: development, scoring and evaluation of rheumatoid arthritis patients and trial profiles. J Rheumatol 1993, 20:561-565. 
10. van Leeuwen MA, Van der Heijde DM, van Rijswijk MH, Houtman PM, van Riel PL, van de Putte LB, Limburg PC: Interrelationship of outcome measures and process variables in early rheumatoid arthritis. A comparison of radiologic damage, physical disability, joint counts, and acute phase reactants. J Rheumato/ 1994, 21:425-429.

11. Smolen JS, Van Der Heijde DM, St Clair EW, Emery $P$, Bathon JM, Keystone E, Maini RN, Kalden JR, Schiff M, Baker D, Han C, Han J, Bala M; Active-Controlled Study of Patients Receiving Infliximab for the Treatment of Rheumatoid Arthritis of Early Onset (ASPIRE) Study Group: Predictors of joint damage in patients with early rheumatoid arthritis treated with high-dose methotrexate without or with concomitant infliximab. Results from the ASPIRE trial. Arthritis Rheum 2006, 54:702-710.

12. Aletaha D, Machold KP, Nell VPK, Smolen JS: The perception of rheumatoid arthritis core set measures by rheumatologists. Results of a survey. Rheumatology 2006, 45:1133-1139.

13. Aletaha D, Smolen JS: The definition and measurement of disease modification in inflammatory rheumatic diseases. Rheum Dis Clin North Am 2006, 32:9-44.

14. Aletaha D, Funovits J, Keystone EC, Smolen JS: Disease activity early in the course of treatment predicts response to therapy after one year in rheumatoid arthritis patients. Arthritis Rheum 2007, 56:3226-3235.

15. Gravallese EM, Harada $Y$, Wang JT, Gorn AH, Thornhill TS, Goldring SR: Identification of cell types responsible for bone resorption in rheumatoid arthritis and juvenile rheumatoid arthritis. Am J Pathol 1998, 152:943-951.

16. Redlich K, Hayer S, Ricci R, David JP, Tohidast-Akrad M, Kollias G, Steiner G, Smolen JS, Wagner EF, Schett G: Osteoclasts are essential for TNF-alpha-mediated joint destruction. J Clin Invest 2002, 110:1419-1427.

17. Gay S, Gay RE, Koopman WJ: Molecular and cellular mechanisms of joint destruction in rheumatoid arthritis: two cellular mechanisms explain joint destruction? Ann Rheum Dis 1993, 52 Suppl 1:S39-S47.

18. Firestein GS: Evolving concepts of rheumatoid arthritis. Nature 2003, 423:356-361.

19. Feldmann M, Brennan FM, Foxwell BM, Maini RN: The role of TNF alpha and IL-1 in rheumatoid arthritis. Curr Dir Autoimmun 2001, 3:188-199.

20. Naka T, Nishimoto N, Kishimoto T: The paradigm of IL-6: from basic science to medicine. Arthritis Res 2002, 4 Suppl 3:S233S242.

21. Aletaha D, Nell VPK, Stamm T, Uffmann M, Pflugbeil S, Machold K, Smolen JS: Acute phase reactants add little to composite disease activity indices for rheumatoid arthritis: validation of a clinical activity score. Arthritis Res Ther 2005, 7:R796-R806.

22. Smolen JS, Han C, Van der Heijde DM, Emery P, Bathon JM, Keystone E, Maini RN, Kalden JR, Aletaha D, Baker D, Han J, Bala M, St Clair EW: Radiographic changes in rheumatoid arthritis patients attaining different disease activity states with methotrexate monotherapy and infliximab plus methotrexate: the impacts of remission and TNF-blockade. Ann Rheum Dis 2008, Jul 7. [Epub ahead of print].

23. van der Heijde D, Simon L, Smolen J, Strand V, Sharp J, Boers M, Breedveld F, Weisman M, Weinblatt M, Rau R, Lipsky P: How to report radiographic data in randomized clinical trials in rheumatoid arthritis: guidelines from a roundtable discussion. Arthritis Rheum 2002, 47:215-218.

24. Smolen JS, van der Heijde DM, Aletaha D, Xu S, Han J, Baker D, St Clair EW: Progression of radiographic joint damage in rheumatoid arthritis: independence of erosins and joint space narrowing. Ann Rheum Dis 2008, Oct 28. [Epub ahead of print].

25. Cohen SB, Dore RK, Lane NE, Ory PA, Peterfy CG, Sharp JT, van der Heijde D, Zhou L, Tsuji W, Newmark R; Denosumab Rheumatoid Arthritis Study Group: Denosumab treatment effects on structural damage, bone mineral density, and bone turnover in rheumatoid arthritis: a twelve-month, multicenter, randomized, double-blind, placebo-controlled, phase II clinical trial. Arthritis Rheum 2008, 58:1299-1309.

26. Fries JF, Spitz $P$, Kraines RG, Holman HR: Measurement of patient outcome in arthritis. Arthritis Rheum 1980, 23:137-145.

27. Ware JE J, Sherbourne CD: The MOS 36-item short-form health survey (SF-36). I. Conceptual framework and item selection. Med Care 1992, 30:473-483.

28. Vita AJ, Terry RB, Hubert HB, Fries JF: Aging, health risks, and cumulative disability. N Engl J Med 1998, 338:1035-1041.

29. Drossaers-Bakker KW, de Buck M, van Zeben D, Zwinderman $\mathrm{AH}$, Breedveld FC, Hazes JM: Long-term course and outcome of functional capacity in rheumatoid arthritis: the effect of disease activity and radiologic damage over time. Arthritis Rheum 1999, 42:1854-60.

30. Welsing PM, van Gestel AM, Swinkels HL, Kiemeney LA, van Riel PL: The relationship between disease activity, joint destruction, and functional capacity over the course of rheumatoid arthritis. Arthritis Rheum 2001, 44:2009-2017.

31. Aletaha D, Smolen J, Ward MM: Measuring function in rheumatoid arthritis: identifying reversible and irreversible components. Arthritis Rheum 2006, 54:2784-2792.

32. Aletaha $D$, Ward MM: Duration of rheumatoid arthritis influences the degree of functional improvement in clinical trials. Ann Rheum Dis 2006, 65:227-233.

33. Pincus T, Callahan LF: Early mortality in RA predicted by poor clinical status. Bull Rheum Dis 1992, 41:1-4.

34. Pincus T, Brooks RH, Callahan LF: Prediction of long-term mortality in patients with rheumatoid arthritis according to simple questionnaire and joint count measures. Ann Intern Med 1994, 120:26-34.

35. Isomaki H: Long-term outcome of rheumatoid arthritis. Scand J Rheumatol 1992, 95 (Suppl):3-8.

36. Wolfe F, Michaud K, Gefeller O, Choi HK: Predicting mortality in patients with rheumatoid arthritis. Arthritis Rheum 2003, 48: 1530-1542.

37. Yelin E, Trupin L, Wong B, Rush S: The impact of functional status and change in functional status on mortality over 18 years among persons with rheumatoid arthritis. J Rheumatol 2002, 29:1851-1857.

38. Michaud K, Wolfe F: Comorbidities in rheumatoid arthritis. Best Pract Res Clin Rheumatol 2007, 21:885-906.

39. Jacobsson LT, Turesson C, Gülfe A, Kapetanovic MC, Petersson IF, Saxne T, Geborek P: Treatment with tumor necrosis factor blockers is associated with a lower incidence of first cardiovascular events in patients with rheumatoid arthritis. J Rheumatol 2005, 32:1213-1218.

40. Ridker PM, Hennekens $\mathrm{CH}$, Buring JE, Rifai N: C-reactive protein and other markers of inflammation in the prediction of cardiovascular disease in women. N Engl J Med 2000, 342:836-843.

41. Shah $\mathrm{SH}, \mathrm{Newby}$ LK: C-reactive protein: a novel marker of cardiovascular risk. Cardiol Rev 2003, 11:169-179.

42. Baecklund E, Iliadou A, Askling J, Ekbom A, Backlin C, Granath F, Catrina Al, Rosenquist R, Feltelius N, Sundström C, Klareskog L: Association of chronic inflammation, not its treatment, with increased lymphoma risk in rheumatoid arthritis. Arthritis Rheum 2006, 54:692-701.

43. Ethgen $\mathrm{O}$, Kahler KH, Kong SX, Reginster JY, Wolfe F: The effect of health related quality of life on reported use of health care resources in patients with osteoarthritis and rheumatoid arthritis: a longitudinal analysis. J Rheumatol 2002, 29:11471155.

44. Yelin E, Wanke LA: An assessment of the annual and longterm direct costs: the impact of poor function and functional decline. Arthritis Rheum 1999, 42:1209-1218.

45. Ward MM, Javitz HS, Yelin EH: The direct cost of rheumatoid arthritis. Value Health 2000, 3:243-252.

46. Pincus T, Callahan LF, Sale WG, Brooks AL, Payne LE, Vaughn WK: Severe functional declines, work disability, and increased mortality in seventy-five rheumatoid arthritis patients studied over nine years. Arthritis Rheum 1984, 27:864-872.

47. Sokka T, Kautiainen H, Mottonen T, Hannonen P: Work disability in rheumatoid arthritis 10 years after the diagnosis. J Rheumatol 1999, 26:1681-1685.

48. Wolfe FE, Hawley DJ: The longterm outcome of rheumatoid arthritis. Work disability: a prospective 18 year study of $\mathbf{8 1 6}$ patients. J Rheumatol 1998, 25:2108-2117.

49. Smolen JS, Han C, van der Heijde D, Emery P, Bathon JM, Keystone E, Kalden JR, Schiff M, Bala M, Baker D, Han J, Maini RN St Clair EW: Infliximab treatment maintains employability in patients with early rheumatoid arthritis. Arthritis Rheum 2006 , 54:716-722.

50. Fries JF: Safety, cost and effectiveness issues with disease modifying anti-rheumatic drugs in rheumatoid arthritis. Ann Rheum Dis 1999, 58 Suppl 1:186-189.

51. Kobelt $G$, Jönsson B: The burden of rheumatoid arthritis and 
access to treatment: outcome and cost-utility of treatments. Eur J Health Econ 2008, 8 (Suppl 2):S95-S106.

52. van Gestel AM, Anderson JJ, van Riel PL, Boers M, Haagsma CJ, Rich B, Wells G, Lange ML, Felson DT: ACR and EULAR improvement criteria have comparable validity in rheumatoid arthritis trials. American College of Rheumatology European League of Associations for Rheumatology. J Rheumatol 1999, 26:705-711.

53. Aletaha D, Funovits J, Smolen JS, Kvien T: The perception of improvement in patients with rheumatoid arthritis varies with disease activity at baseline. Arthritis Rheum 2008, in press.

54. Aletaha D, Funovits J, Smolen JS: The importance of reporting disease activity states in clinical trials of rheumatoid arthritis. Arthritis Rheum 2008, 58:2622-2631.

55. Aletaha D, Landewe R, Karonitsch T, Bathon J, Boers M, Bombardier C, Bombardieri S, Choi H, Combe B, Dougados M, Emery P, Gomez-Reino J, Keystone E, Koch G, Kvien TK, Martin-Mola E, Matucci-Cerinic M, Michaud K, O'Dell J, Paulus H, Pincus T, Richards P, Simon L, Siegel J, Smolen JS, Sokka T, Strand V, Tugwell $P$, van der Heijde $D$, van Riel $P$, Vlad $S$, van Vollenhoven R, Ward M, Weinblatt M, Wells G, White B, Wolfe F, Zhang B, Zink $A$, Felson D: EULAR/ACR recommendations on reporting disease activity in clinical trials of rheumatoid arthritis. Ann Rheum Dis 2008, in press.

56. Emery $P$, Breedveld FC, Hall S, Durez $P$, Chang DJ, Robertson D, Singh A, Pedersen RD, Koenig AS, Freundlich B: Comparison of methotrexate monotherapy with a combination of methotrexate and etanercept in active, early, moderate to severe rheumatoid arthritis (COMET): a randomised, double-blind, parallel treatment trial. Lancet 2008, 372:375-382.

57. Van der Heijde DM, van Riel PL, van Leeuwen MA, van't Hof MA, van Rijswijk MH, van de Putte LB: Older versus younger onset rheumatoid arthritis: results at onset and after 2 years of a prospective followup study of early rheumatoid arthritis. $J$ Rheumatol 1991, 18:1285-1289.

58. Plant MJ, Jones PW, Saklatvala J, Ollier WE, Dawes PT: Patterns of radiological progression in rheumatoid arthritis: results of an 8 year prospective study. J Rheumatol 1998, 25:417-426.

59. Hayer S, Redlich K, Korb A, Hermann S, Smolen J, Schett G: Tenosynovitis and osteoclast formation as the initial preclinical changes in a murine model of inflammatory arthritis. Arthritis Rheum 2007, 56:79-88.

60. van der Heide A, Jacobs JW, Bijlsma JW, Heurkens AH, BoomaFrankfort C, van der Veen MJ, Haanen HC, Hofman DM, van Albada-Kuipers GA, ter Borg EJ, Brus HL, Dinant HJ, Kruize AA, Schenk $Y$ : The effectiveness of early treatment with 'secondline' antirheumatic drugs. A randomized, controlled trial. Ann Intern Med 1996, 124:699-707.

61. Lard LR, Visser H, Speyer I, vander Horst-Bruinsma IE, Zwinderman $\mathrm{AH}$, Breedveld FC, Hazes JM: Early versus delayed treatment in patients with recent-onset rheumatoid arthritis: comparison of two cohorts who received different treatment strategies. Am J Med 2001, 111:446-451.

62. Nell V, Machold KP, Eberl G, Stamm TA, Uffmann M, Smolen JS: Benefit of very early referral and very early therapy with disease-modifying anti-rheumatic drugs in patients with early rheumatoid arthritis. Rheumatology (Oxford) 2004, 43:906-914.

63. Aletaha D, Breedveld FC, Smolen JS: The need for new classification criteria for rheumatoid arthritis. Arthritis Rheum 2005, 52:3333-3336.

64. Grigor C, Capell H, Stirling A, McMahon AD, Lock P, Vallance R, Kincaid W, Porter D: Effect of a treatment strategy of tight control for rheumatoid arthritis (the TICORA study): a singleblind randomised controlled trial. Lancet 2004, 364:263-269.

65. Verstappen SM, Jacobs JW, van der Veen MJ, Heurkens AH, Schenk Y, ter Borg EJ, Blaauw AA, Bijlsma JW; Utrecht Rheumatoid Arthritis Cohort study group: Intensive treatment with methotrexate in early rheumatoid arthritis: aiming for remission. Computer Assisted Management in Early Rheumatoid Arthritis (CAMERA, an open-label strategy trial). Ann Rheum Dis 2007, 66:1443-1449.

66. Goekoop-Ruiterman YP, De Vries-Bouwstra JK, Allaart CF, Van Zeben D, Kerstens PJ, Hazes JM, Zwinderman AH, Ronday HK, Han KH, Westedt ML, Gerards AH, van Groenendael JH, Lems WF, van Krugten MV, Breedveld FC, Dijkmans BA: Clinical and radiographic outcomes of four different treatment strategies in patients with early rheumatoid arthritis (the BeSt study): a randomized, controlled trial. Arthritis Rheum 2005, 52:33813390.

67. Smolen JS, Aletaha D, Koeller M, Weisman M, Emery P: New therapies for the treatment of rheumatoid arthritis. Lancet 2007, 370:1861-1874.

68. Mierau M, Schoels M, Gonda G, Fuchs J, Aletaha D, Smolen JS: Assessing remission in clinical practice. Rheumatology (Oxford) 2007, 46:975-979.

69. Sokka T, Pincus T: Most patients receiving routine clinical care for rheumatoid arthritis in 2001 did not meet inclusion criteria for most recent clinical trials or American College of Rheumatology remission criteria. J Rheumatol 2003, 30:1138-1146.

70. Smolen JS, Han C, Bala M, Maini RN, Kalden JR, van der Heijde D, Breedveld FC, Furst DE, Lipsky PE; ATTRACT Study Group: Evidence of radiographic benefit of treatment with infliximab plus methotrexate in rheumatoid arthritis patients who had no clinical improvement: a detailed subanalysis of data from the anti-tumor necrosis factor trial in rheumatoid arthritis with concomitant therapy study. Arthritis Rheum 2005, 52:10201030.

71. Landewé R, van der Heijde D, Klareskog L, van Vollenhoven R, Fatenejad S: Disconnect between inflammation and joint destruction after treatment with etanercept plus methotrexate: results from the trial of etanercept and methotrexate with radiographic and patient outcomes. Arthritis Rheum 2006, 54: 3119-3125.

72. Smolen JS, Aletaha D, Grisar J, Redlich K, Steiner G, Wagner O: The need for prognosticators in rheumatoid arthritis. Biological and clinical markers: where are we now? Arthritis Res Ther 2008, 10:208.

73. Mitchell DM, Spitz PW, Yound DY, Bloch DA, McShane DJ, Fries JF: Survival, prognosis, and causes of death in rheumatoid arthritis. Arthritis Rheum 1986, 29:706-714.

74. Scott DG, Bacon PA, Allen C, Elson CJ, Wallington T: IgG rheumatoid factor, complement and immune complexes in rheumatoid synovitis and vasculitis: comparative and serial studies during cytotoxic therapy. Clin Exp Immunol 1981, 43: 54-63.

75. Voskuyl AE, Hazes JM, Zwinderman $\mathrm{AH}$, Paleolog EM, van der Meer FJ, Daha MR, Breedveld FC: Diagnostic strategy for the assessment of rheumatoid vasculitis. Ann Rheum Dis 2003, 62:407-413.

76. Weinblatt ME: Rheumatoid arthritis in 2003: where are we now with treatment? Ann Rheum Dis 2003, 62 (Suppl II):ii94-ii96.

77. Pincus T, Yazici Y, Sokka T, Aletaha D, Smolen JS: Methotrexate as the 'anchor drug' for the treatment of early rheumatoid arthritis. Clin Exp Rheumatol 2003, 21 (Suppl 31):S178-S185.

78. Choi HK, Hernan MA, Seeger JD, Robins JM, Wolfe F: Methotrexate and mortality in patients with rheumatoid arthritis: a prospective study. Lancet 2002, 359:1173-1177.

79. Elliott MJ, Maini RN, Feldmann M, Kalden JR, Antoni C, Smolen JS, Leeb B, Breedveld FC, Macfarlane JD, Bijl H, Woody JN: Randomised double-blind comparison of chimeric monoclonal antibody to tumour necrosis factor alpha (cA2) versus placebo in rheumatoid arthritis. Lancet 1994, 344:1105-1110.

80. Feldmann M, Maini RN: Anti-TNF alpha therapy of rheumatoid arthritis: what have we learned? Annu Rev Immunol 2001, 19: 163-196.

81. Jacobsson LT, Turesson C, Nilsson JA, Petersson IF, Lindqvist E, Saxne T, Geborek P: Treatment with TNF blockers and mortality risk in patients with rheumatoid arthritis. Ann Rheum Dis 2007, 66:670-675.

82. Wolfe F, Michaud K: Heart failure in rheumatoid arthritis: rates, predictors, and the effect of anti-tumor necrosis factor therapy. Am J Med 2004, 116:305-311.

83. Smolen JS, Sokka T, Pincus T, Breedveld FC: A proposed treatment algorithm for rheumatoid arthritis: aggressive therapy, methotrexate, and quantitative measures. Clin Exp Rheumatol 2003, 21 (5 Suppl 31):S209-S210.

84. Boers M, Verhoeven AC, Markusse HM, van de Laar MA, Westhovens R, van Denderen JC, van Zeben D, Dijkmans BA, Peeters AJ, Jacobs $P$, van den Brink HR, Schouten $H J$, van der Heijde DM, Boonen A, van der Linden S: Randomised comparison of combined step-down prednisolone, methotrexate and sulphasalazine with sulphasalazine alone in early rheumatoid arthritis: a randomised trial. Lancet 1997, 350:309-318.

85. Landewé RB, Boers M, Verhoeven AC, Westhovens R, van de 
Laar MA, Markusse HM, van Denderen JC, Westedt ML, Peeters AJ, Dijkmans BA, Jacobs $P$, Boonen A, van der Heijde DM, van der Linden S: COBRA combination therapy in patients with early rheumatoid arthritis: long-term structural benefits of a brief intervention. Arthritis Rheum 2002, 46:347-356.

86. Wassenberg S, Rau R, Steinfeld P, Zeidler H: Very low-dose prednisolone in early rheumatoid arthritis retards radiographic progression over two years: a multicenter, doubleblind, placebo-controlled trial. Arthritis Rheum 2005, 52: 3371-3380.

87. Mottonen TT, Hannonen PJ, Boers M: Combination DMARD therapy including corticosteroids in early rheumatoid arthritis. Clin Exp Rheumatol 1999, 17(6 Suppl 18):S59-S65.

88. Smolen JS, Aletaha D, Keystone E: Superior efficacy of combination therapy for rheumatoid arthritis. Fact or fiction? Arthritis Rheum 2005, 52:2975-2983.

89. Kärrholm J, Garelick G, Herberts P: Swedish hip replacement register: annual report 2006 [http://www.jru.orthop.gu.se]. 